\title{
Analisis Modal Intelektual Dan Ukuran Perusahaan Terhadap Nilai Perusahaan Melalui Kinerja Perusahaan Sebagai Variabel Antara
}

\author{
${ }^{1}$ Bayu Aji Kurniawan, ${ }^{2}$ Muslichah \\ ${ }^{1,2}$ Sekolah Tinggi Ilmu Ekonomi Malangkucecwara, Indonesia \\ ${ }^{1}$ Email korenpondensi: ajukurniawanbayu@yahoo.com
}

This study examines the effect of intellectual capital and firm size on firm value with the company's financial performance as an intervening variable. The sample used in this study is a food and beverage company that is listed on the Indonesia Stock Exchange (IDX) it the period 2014-2018. Data obtained by 65 samples. Data of this study is analyzed using path analysis. The results show that intellectual capital and firm size had a positive effect oncompany performance and firm value, and company performance mediate the effect of intellectual capital and firm size on firm value.

Keywords: Intelectual Capital, Firm Size, Company Performance, Firm Value

Saran sitasi: Kurniawan, B., \& Muslichah. (2019). Analisis Modal Intelektual Dan Ukuran Perusahaan Terhadap Nilai Perusahaan Melalui Kinerja Perusahaan Sebagai Variabel Antara. Jurnal Akuntansi dan Pajak, 20(1), 66-80. doi: http://dx.doi.org/10.29040/jap.v20i1.574

DOI: http://dx.doi.org/10.29040/jap.v20i1.574

\section{Pendahuluan}

Ekonomi global tumbuh dengan pesat, seiring perkembangan zaman maka intensitas persaingan yang semakin tinggi memaksa sebagian besar perusahaan untuk meningkatkan nilai aset yang dimilikinya untuk bisa mendapatkan laba yang besar. Industri yang sebelumnya bertumpu pada aset berwujud menjadi tergantung pada aset tidak berwujud (Fajarini dan Firmansyah, 2012). Modal intelektual sebagai kekayaan perusahaan yang merupakan kekuatan dibalik penciptaan nilai perusahaan (Firer dan Williams, 2003). Peningkatan modal intelektual dapat mendorong peningkatan nilai melalui kinerja (Bounfour, 2003). Secara umum terdapat keterkaitan antara modal intelektual dan nilai perusahaan.

Selain nilai perusahaan, investor juga memperhatikan indikasi lain untuk melihat seberapa besar prospektif perusahaan dimasa depan sehingga ukuran perusahaan juga dapat dijadikan salah satu indikator (Zuhroh, 2019). Ukuran perusahaan adalah skala perusahaan yang dilihat dari total aktiva perusahaan pada akhir tahun. Total penjualan juga dapat digunakan untuk mengukur besarnya perusahaan (Veronica dan Siddharta, 2005). Ukuran perusahaan menggambarkan besar kecilnya perusahaan. Besar kecilnya usaha tersebut ditinjau dari lapangan usaha yang dijalanakan. Penentuan skala besar kecilnya perusahaan dapat ditentukan berdasarkan total penjualan, total asset, rata-rata tingkat penjualan (Seftianne, 2011). Hasil penelitian sebelumnya menunjukkan bahwa ukuran perusahaan berpengaruh positif signifikan terhadap nilai perusahaan (Rompas, 2013; Ernawati dan Widyawati, 2015). Sebaliknya Setiadharma dan Muslichah (2017) dan Zuhroh (2019) menemukan bahwa ukuran perusahaan tidak berpengaruh terhadap nilai perusahaan. 
Nilai perusahaan juga dipengaruhi oleh modal intelektual. Jika sumber daya intelektual dapat dimanfaatkan secara optimal akan menciptakan modal Intelektual yang unggul di perusahaan. Investor di pasar modal akan menunjukkan penghargaan atas keunggulan modal Intelektual perusahaan yang ditunjukkan dengan permintaan atas saham yang meningkat, yang selanjutnya akan berdampak pada kenaikan nilai perusahaan. Penelitian sebelumnya telah membuktikan bahwa modal intelektual berpengaruh terhadap nilai perusahaan yang diukur dengan harga saham (Shiri et al., 2012; Mhedhbi , 2013; Berzkalnea dan Zelgalvea, 2014; Bchini, 2015; Li dan Zhao,2017). Tetapi Penelitian yang lain menunjukkan bahwa model intelektual tidak berpengaruh terhadap nilai perusahaan (Ferraro \& Veltri; 2011; Mehralian, Rasekh, Akhavan \& Sadeh, 2012; Tanideh, 2013)

Selain modal intelektual dan ukuran perusahaan, nilai perusahaan juga dipengaruhi oleh kinerja perusahaan. Menurut Sihasale (2001), kinerja perusahaan merupakan suatu tampilan keadaan perusahaan selama periode tertentu. Semakin baik kinerja perusahaan maka akan menunjukan prospek perusahaan yang berkualitas baik sehingga pasar akan merespon positif sinyal tersebut dan nilai perusahaan akan meningkat pula (Sujono dan Soebiantoro, 2007). Kinerja perusahaan dapat diukur dari laporan keuangan yang dikeluarkan secara periodik yang memberikan suatu gambaran tentang posisi keuangan perusahaan (Purnomo, 1998). Banyak penelitian terdahulu yang mendukung dugaan bahwa kinerja perusahaan (profitability) berpengaruh positif terhadap nilai perusahaan (Khlif et al.,2015; Nabavand and Rezaei. 2015; Heidarpoor and Malekpoor 2012; Nawaiseh, 2017).

Penelitian ini berbeda dengan penelitian sebelumnya. Pertama, sudah ada beberapa peneliti yang menguji pengaruh ukuran perusahaan terhadap nilai perusahaan . tepai hasil penelitian sebelumnya masih tidak konsisten (Rompas, 2013; Ernawati dan Widyawati, 2015; Setiadharma dan Muslichah, 2017). Karena ketidak konsistenan tersebut peneliti memasukkan kinerja perusahaan sebagai variabel yang memediasi hubungan kedua variabel tersebut. Kedua, sepengetahuan peneliti belum ada penelitian yang mengintegrasi pengaruh modal intelektual dan ukuran perusahaan terhadap nilai perusahaan melalui kinerja perusahaan ke dalam satu model penelitian. Berdasarkan alasan tersebut penelitian ini bertujuan untuk menganalisis pengaruh modal intelektual dan ukuran perusahaan terhadap nilai perusahaan dengan kinerja perusahaan sebagai variabel antara.

Karakteristik penting pelaporan keuangan yaitu Ketepatan Penyampaian waktu pelaporan keuangan (timeliness). Laporan keuangan yang diberikan tepat waktu mengurangi resiko yang ketidaksesuaian didalam penafsiran informasi laporan keuangan. Laporan keuangan public sebagai sinyal perusahaan menunjukan informasi dalam kebutuhan pembuatan keputusan investor (McGee, 2007); ( McGee \& Yuan, 2008). Relevansi informasi dikomunikasikan hilang jika terlambat disampaikan. Apabila informasi tidak disampaian diluar jangka yang ditetapkan menyebabkan nilai informasi berkurang dalam mengambil suatu keputusan untuk penentuan tindakan masa akan datang (Raesya, 2010).

\section{Tinjauan Pustaka}

\subsection{Signalling Theory}

Teori signal (Signalling Theory) menyatakan bahwa perusahaan secara sengaja memberikan sinyal kepada pasar, dengan demikian diharapkan pasar akan bereaksi dan memberi pengaruh terhadap harga saham perusahaan. Teori sinyal relevan untuk menjelaskan masalah asimetri informasi antara perusahaan dengan para calon investor (Morris, 1987). informasi yang dipublikasikan sebagai suatu pengumuman akan memberikan signal bagi investor dalam pengambilan keputusan investasi(jogiyanto 2000.pdf, n.d.). Jika pengumuman tersebut mengandung nilai positif, maka diharapkan pasar akan bereaksi pada waktu pengumuman tersebut diterima oleh pasar. 


\subsection{Resource Based Theory}

Resource Based Theory adalah penjelasan berbasis efisiensi tentang kinerja organisasi unggul yang berkelanjutan. Ada banyak definisi sumber daya. Sumber daya organisasi dapat berupa asetnya (Barney, 1991; Wernerfelt, 1984), kompetensi dan kemampuannya (Stalk, et.al., 1992), dan juga pengetahuannya (Spender dan Grant, 1996 ). Ketika sumber daya perusahaan menambah nilai perusahaan, langka atau unik dan biaya yang besar jika ditiru dan tidak bisa disubstitusi, RBV bisa digunakan sebagai evaluasi terhadap potensial dari strategi alternative yang dihadapi perusahaan (Barney:2001).

\subsection{Nilai Perusahaan}

Nilai perusahaan adalah konsep penting dari investor yaitu sebagai indikator evaluasi pasar suatu perusahaan secara keseluruhan (Nurlela, 2008) oleh karena itu, nilai perusahaan didefinisikan sebagai harga jual perusahaan yang dipertimbangkan sehubungan dengan investor prospektif ketika perusahaan akan dilikuidasi (Wahyudi dan Pawestri, 2006; Rahmawati, 2015)Memaksimalkan nilai perusahaan sangat penting artinya bagi suatu perusahaan, karena dengan memaksimalkan nilai perusahaan berarti juga memaksimalkan tujuan utama perusahaan. Meningkatnya nilai perusahaan adalah sebuah prestasi yang sesuai dengan keinginan para pemiliknya, karena dengan meningkatnya nilai perusahaan, maka kesejahteraan para pemilik juga akan meningkat.

\subsection{Modal Intelektual}

Modal intelektual adalah asset tidak berwujud berupa sumber daya informasi serta pengetahuan yang berfungsi untuk meningkatkan kemampuan bersaing serta dapat meningkatkan kinerja perusahaan. Metode $\mathrm{VAIC}^{\mathrm{TM}}$ dikembangkan oleh Pulic (1998), didesain untuk menyajikan informasi tentang value creation efficiency dari aset berwujud dan aset tidak berwujud yang dimiliki perusahaan. Model ini dimulai dengan kemampuan perusahaan untuk menciptakan value added (VA). Value added adalah indikator paling objektif untuk menilai keberhasilan bisnis dengan menunjukan kemampuan perusahaan dalam menciptakan nilai (value creation) (Pulic, 1998). VA dihitung sebagai selisih antara output dan input (Pulic, 2000). Tan et al. (2007) meyatakan bahwa output (out) merepresentasikan revenue dan mencakup seluruh produk dan jasa yang dijual dipasar, sedangkan input (in) mencakup seluruh beban yang digunakan dalam memperoleh revenue. Komponen utama dari VAIC $^{\mathrm{TM}}$ dalam praktiknya ada tiga pengukuran modal intelektual yaitu, Value Added Capital Employee (VAHA), Value Added Human Capital (VAHU) dan Structural Capital Value Added (STVA).

\subsection{Ukuran Perusahaan}

Ukuran perusahaan pada dasarnya adalah pengelompokan perusahaan kedalam beberapa kelompok, di antaranya perusahaan besar, sedang dan kecil. Skala perusahaan merupakan ukuran yang dipakai untuk mencerminkan besar kecilnya perusahaan yang didasarkan kepada total aset perusahaan (Suwito dan Herawaty:2005). Ukuran perusahaan adalah skala perusahaan yang dilihat dari total aktiva perusahaan pada akhir tahun. Total penjualan juga dapat digunakan untuk mengukur besarnya perusahaan (Veronica dan Siddharta:2005). Ukuran perusahaan menggambarkan besar kecilnya perusahaan. Besar kecilnya usaha tersebut ditinjau dari lapangan usaha yang dijalanakan. Penentuan skala besar kecilnya perusahaan dapat ditentukan berdasarkan total penjualan, total asset, rata-rata tingkat penjualan (Seftianne:2011).

\subsection{Kinerja Perusahaan}

Kinerja keuangan perusahaan merupakan suatu pengukuran yang menggambarkan keefektifan perusahaan dalam pengelolaan aset yang dimiliki perusahaan untuk kegiatan operasional dalam memperoleh laba (Kartikasari, 2016). Kinerja perusahaan (companies performance) merupakan sesuatu yang dihasilkan oleh suatu perusahaan dalam periode tertentu dengan mengacu kepada standar yang 
ditetapkan. Pengukuran aktifitas kinerja perusahaan dirancang untuk menaksir bagaimana kinerja aktivitas dan hasil akhir yang dicapai.

\subsection{Pengembangan Hipotesis}

\subsubsection{Pengaruh Modal Intelektual terhadap Nilai Perusahaan}

Modal intelektual mengaitkan secara positif dengan nilai perusahaan yang diukur dengan nilai pasar ke nilai buku (Poraghajan, 2013); modal yang digunakan dan modal manusia memiliki hubungan positif dengan nilai perusahaan (Ming, 2012); dan modal intelektual mendorong rasio harga ke laba yang lebih tinggi (Femianti, 2014). Menurut Edvinsson \& Malone (1997) salah satu keunggulan modal intelektual adalah sebagai alat untuk menentukan nilai perusahaan.

H1: Modal intelektual berpengaruh positif terhadap nilai perusahaan.

\subsubsection{Pengaruh Ukuran Perusahaan Terhadap Nilai Perusahaan}

Menurut Atmaja (2008) ukuran perusahaan adalah skala yang mengklasifikasikan ukuran perusahaan menggunakan berbagai metode: total aset, logsize, nilai pasar saham, total penjualan dan sejenisnya. Efek positif dari ukuran perusahaan pada akses ke sumber pendanaan dapat meningkatkan kepercayaan investor terhadap kenaikan nilai perusahaan yang tercermin dalam harga pasar saham (Pantow et al., 2015). Menurut Pramelasari, (2010) perusahaan yang mampu mengelola aset perusahaan secara maksimal akan mampu menciptakan value added dan berpengaruh terhadap peningkatan niai perusahaan. Ukuran perusahaan dianggap mampu mempengaruhi nilai perusahaan.

H2: Ukuran perusahaan berpengaruh positif terhadap nilai perusahaan.

\subsubsection{Pengaruh Modal Intelektual Terhadap Kinerja Perusahaan}

Appuhami (2007) menyatakan bahwa semakin besar nilai modal intelektual (VAICTM) maka akan menciptakan value added bagi perusahaan. Selain itu, jika modal intelektual merupakan sumber daya yang terukur untuk peningkatan competitive advantages, maka modal intelektual akan memberikan kontribusi terhadap kinerja perusahaan (Abdolmohammadi: 2005). Sebagian besar hasil penelitian, seperti misalnya penelitian Chen et al. (2005), Ulum et al. (2008), Solikhah et al. (2010), Entika (2012), Soedaryono et al. (2012), serta Sunarsih \& Mendra (2012), menunjukkan bahwa modal intelektual berpengaruh positif terhadap kinerja keuangan perusahaan. Perusahaan yang mampu mengelola pengetahuan dan sumber daya intelektualnya dengan baik, diyakini mampu menciptakan value added dan keunggulan bersaing dengan melakukan inovasi serta research and development yang nantinya akan bermuara pada peningkatan kinerja keuangan perusahaan. Hal tersebut senada dengan konsep knowledge-based theory (Solikhah et al., 2010 dan Entika, 2012). Dari kajian konsep dan empiris tersebut, maka hipotesis peneliti adalah modal intelektual berpengaruh positif terhadap kinerja perusahaan.

H3: Modal intelektual berpengaruh positif terhadap kinerja perusahaan

\subsubsection{Pengaruh Ukuran Perusahaan Terhadap Kinerja Perusahaan}

Menurut Indarti dan Extralyus (2013) Ukuran perusahan merupakan nilai yang menunjukan besar kecilnya perusahaan.terdapat berbagai proksi yang biasanya digunakan untuk mewakili ukuran perusahaan, total aset, jumlah penjualan, dan kapitalisasi pasar. Beberapa hasil studi empiris tentang pengaruh ukuran perusahaan terhadap kinerja perusahaan dengan objek perusahaan di Indonesia belum konsisten. Berdasarkan penelitian Rompas (2013) yang menunjukkan bahwa ukuran perusahaan memiliki efek positif dan signifikan terhadap kinerja perusahaan dan penelitian Darmawati (2004) yang menyatakan perusahaan besar pada dasarnya memiliki kekuatan finansial yang lebih besar dalam menunjang kinerja. Maka peneliti memberikan hipotesis ukuran perusahaan berpengaruh positif terhadap kinerja perusahaan berdasarkan hasil penelitian yang dilakukan oleh Rompas (2013). 
H4: Ukuran perusahaan berpengaruh positif terhadap kinerja perusahaan.

\subsubsection{Pengaruh Kinerja Perusahaan Terhadap Nilai Perusahaan}

Kinerja keuangan perusahaan sangat terkait dengan Return on Asset (ROA) yang dapat digunakan untuk mengukur tingkat pengembalian aset. ROA yang positif menunjukkan bahwa dari total aktiva yang dipergunakan untuk beroperasi mampu menghasilkan laba bagi perusahaan dan sebaliknya. Semakin tinggi ROA akan semakin baik kinerja perusahaan, karena dana yang diinvestasikan dalam aset dapat menghasilkan earning after tax yang semakin tinggi (Pertiwi, 2014). Banyak penelitian terdahulu yang mendukung dugaan bahwa kinerja perusahaan (profitability) berpengaruh positif terhadap nilai perusahaan antara lain Allazy (2013) dan Mahendra Dj et al. (2012).

H5: Kinerja perusahaan berpengaruh positif terhadap nilai perusahaan.

\subsubsection{Pengaruh Modal Intelektual terhadap} nilai perusahaan melalui kinerja perusahaan.

Modal intelektual diyakini dapat berperan penting dalam peningkatan kinerja keuangan. Jika modal intelektual merupakan sumber daya yang terukur untuk peningkatan competitive advantages, maka modal intelektual akan memberikan kontribusi terhadap kinerja perusahaan (Abdolmohammadi: 2005). Ketika laporan keuangan perusahaan memperlihatkan hasil yang memuaskan maka hal ini akan memberikan sinyal kepada investor bahwa kinerja perusahaan berjalan dengan baik
(Signalling Theory). Jika kinerja perusahaan baik maka akan menciptakan nilai perusahaan yang baik.

H6: Modal Intelektual berpengaruh positif terhadap nilai perusahaan melalui kinerja perusahaan.

\subsubsection{Pengaruh Ukuran Perusahaan terhadap nilai perusahaan melalui kinerja perusahaan.}

Penelitian tentang pengaruh ukuran perusahaan terhadap Kinerja Perusahaan juga telah dilakukan oleh Latana ulfa Syahida (2017), menyatakan bahwa kinerja perusahaan berpengaruh signifikan terhadap kinerja perusahaan dalam pembahasannya menyatakan perusahaan yang besar memiliki total aktiva yang besar pula sehingga dapat menarik investor menanamkan modal dan akhirnya akan berpengaruh pada produktivitas perusahaan dan meningkatnya laba perusahaan. Semakin baik kinerja perusahaan maka akan menunjukan prospek perusahaan yang berkualitas baik sehingga pasar akan merespon positif sinyal tersebut dan nilai perusahaan akan meningkat pula (Sujono dan Soebiantoro, 2007). berdasarkan hal tersebut investor sangat tertarik jika perusahaan berhasil mendorong kinerja perusahaan untuk menghasilkan laba dan juga nilai perusahaan yang baik.

H7: Ukuran perusahaan berpengaruh positif terhadap nilai perusahaan melalui kinerja perusahaan.

Berdasarkan pengembangan hipotesis diatas maka model penelitian ini dapat digambarkan pada Gambar 1 berikut.

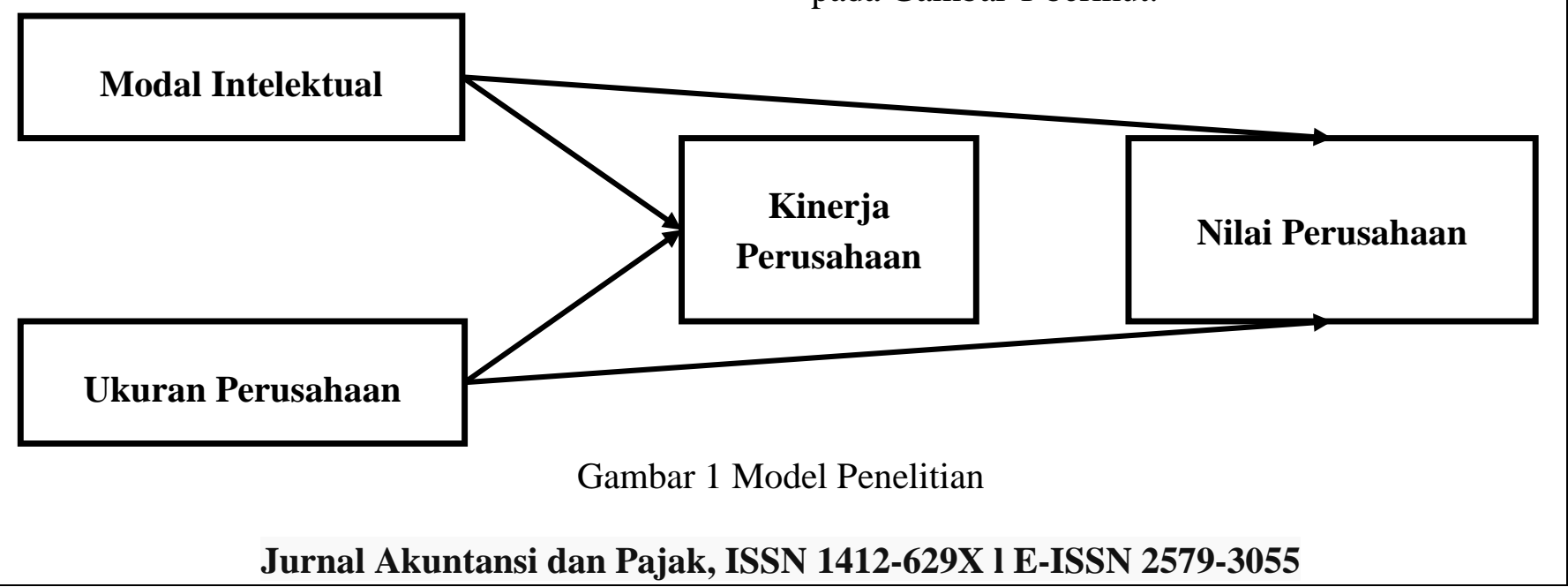




\section{Metode Penelitian}

\subsection{Populasi Dan Sampel Penelitian}

Dalam penelitian ini populasi yang diteliti adalah perusahaan manufaktur sektor food and beverages yang terdaftar di BEI tahun 2014-2018. Sedangkan sample diambil dengan menggunakan teknik Purposive Sampling. Berdasarkan teknik pengambilan sampel, maka peneliti menentukan kriteria sebagai berikut: a. Terdaftar di Bursa Efek Indonesia (BEI) sektor food and beverage.

b. Menerbitkan laporan keuangan secara berturut-turut dari tahun 2014-2018.

c. Memiliki data lengkap yang memudahkan dalam melakukan penelitian.

Tabel 1 berikut menyajikan penggolongan sampel berdasarkan kriteria yang telah ditentukan diatas:

Tabel 1

Prosedur Pemilihan Sampel

\begin{tabular}{|c|l|c|}
\hline No. & \multicolumn{1}{|c|}{ Keterangan } & $\begin{array}{c}\text { Jumlah } \\
\text { Perusahaan }\end{array}$ \\
\hline 1. & Terdaftar di Bursa Efek Indonesia sektor food and beverage. & 18 \\
\hline 2. & $\begin{array}{l}\text { Perusahaan yang tidak menerbitkan laporan keuangan tahunan dalam kurun } \\
\text { waktu 2014-2018. }\end{array}$ & $(5)$ \\
\hline 3. & Menerbitkanlaporankeuangansecaraberturut-turutdaritahun 2014-2018. & 13 \\
\hline 4. & Memiliki data lengkap yang memudahkan dalam melakukan penelitian. & 13 \\
\hline 5. & Jumlahsampelpenelitianselamaperiode 5 tahunatauselamaperiode 2014-2018. & 65 \\
\hline
\end{tabular}

\subsection{Pengujian Hipotesis}

\subsubsection{Analisis Jalur}

Analisis jalur digunakan untuk menguji pengaruh variabel intervening juga untuk menganalisis pola hubungan antar variabel dengan tujuan untuk mengetahui pengaruh langsung maupun tidak langsung seperangkat variabel bebas (eksogen) terhadap variabel terikat (endogen) (Ghozali, 2011). Analisis jalur merupakan perluasan dari analisis regresi linear berganda. Pada dasarnya koefisien jalur adalah koefisien yang distandarkan (standardized regression weights) atau membandingkan koefisien indirect effect (pengaruh tidak langsung) dengan koefisien direct effect (pengaruh langsung). Adapun persamaan regresi dapat dirumuskan sebagai berikut:

ROA $=\alpha+$ p2 VAIC + p3 Ln Asset e1 ... (1)

PBV $=\alpha+$ p1 VAIC + P4 Ln Asset + P5 ROA e2 ... (2)

Keterangan:

$\mathrm{ROA}=$ Kinerja Keuangan (Return On Asset)

VAIC = Value Added Intellectual Coefficients

PBV = Nilai Perusahaan (Price to Book Value)

Ln Asset = Ukuran Perusahaan ( Log n Asset )

$\alpha \quad=$ konstanta

p1 = Koefisien jalur PBV dengan VAIC p2 = Koefisien jalur ROA dengan VAIC

p3 = Koefisien jalur ROA dengan Ln Asset

p4 = Koefisien jalur Ln Asset dengan PBV

p5 = Koefisien jalur ROA dengan PBV

e1 = Residual atas Kinerja Keuangan

e2 = Residual atas Nilai Perusahaan

\subsubsection{Uji Koefisiensi Determinasi $\left(R^{2}\right)$}

Uji koefisiensi determinasi yaitu untuk melihat kemampuan variabel independen dalam menjelaskan variasi perubahan variabel dependen. Nilai koefisien adalah antara 0 dan 1. Nilai R2 yang kecil berarti kemampuan variabelvariabel independen dalam menjelaskan variasi variabel dependen amat terbatas (Ghozali, 2011). Nilai yang mendekati 1 (satu) berarti variabelvariabel independen memberikan hampir semua informasi yang dibutuhkan untuk memprediksi variasi variabel dependen (Ghozali, 2011).

\section{Hasil dan Pembahasan}

\subsection{Hasil penelitian}

\subsubsection{Hasil Analisis Deskriptif}

Tabel 2 berikut menggambarkan profil data penelitian yang menjelaskan data rata-rata, minimum, maksimum dan deviasi standard dari variabel yang diteliti. 
Table 2

Statistif Deskriptif Variabel

\begin{tabular}{|l|c|c|c|c|}
\hline & Minimum & Maximum & Rata -rata & Deviasi Std \\
\hline Nilai Perusahaan & $-1,926$ & 5,491 & 0,9200 & 1,5469 \\
\hline Struktur Modal & 18,224 & $29, / 736$ & 26,4552 & 3,3255 \\
\hline Kebijakan Dividen & $-0,089$ & 0,527 & 0,0970 & 0,1158 \\
\hline Profitabilitas & 0,54 & 45,47 & 5,1840 & 7,9912 \\
\hline
\end{tabular}

Note : Data diolah peneliti, 2019

\section{1) Modal Intelektual}

Hasil pengujian statistik deskriptif pada tabel 4, dapat diketahui bahwa nilai minimum Modal Intelektual sebesar -1,926 dan nilai maksimum sebesar 5,491. Hal ini menunjukkan bahwa besarnya Modal Intelektual pada sampel penelitian ini kisaran antara -1,926 sampai 5,491. Dengan rata-rata (Mean) 0,9200 dan standar deviasi sebesar 1,5469. Nilai rata-rata (Mean) mengartikan besarnya modal intelektual yang dihasilkan seluruh perusahaan selama periode tersebut sebesar 0,9200 dan standar deviasi menggambarkan penyimpangan data sebesar 1,5469. Modal Intelektual tertinggi dicapai perusahaan PT Multi Bintang Indonesia Tbk pada tahun 2017 sedangkan nilai Modal Intelektual terendah dialami perusahaan PT Indofood CBP Sukses Makmur Tbk pada tahun 2018.

2) Ukuran Perusahaan

Hasil pengujian statistik deskriptif pada tabel 4, dapat diketahui bahwa nilai minimum Ukuran Perusahaan sebesar 18,224 dan nilai maksimum sebesar 29,736. Hal ini menunjukkan bahwa besarnya Ukuran Perusahaan pada sampel penelitian ini berkisar antara 18,224 sampai 29,736. Dengan rata-rata (Mean) 26,455 dan standar deviasi yaitu 3,325. Nial rata-rata (Mean) mengartikan besarnya ukuran perusahaan yang dihasilkan seluruh perusahaan selama periode tersebut sebesar 26,455 dan standar deviasi menggambarkan penyimpangan data sebesar 3,325 . Nilai Ukuran Perusahaan tertinggi dicapai perusahaan PT Multi Bintang Indonesia Tbk tahun 2017 dan nilai ukuran perusahaan terendah dialami perusahaanPT Indofood Sukses Makmur Tbk pada tahun 2014.

\section{3) Kinerja Perusahaan}

Hasil pengujian statistik deskriptif pada tabel 4, dapat diketahui bahwa nilai minimum Kinerja Perusahaan (Return On Assets) sebesar 0,089 dan nilai maksimum sebesar 0,527. Hal ini menunjukkan bahwa besarnya (Return On Assets) pada sampel penelitian ini berkisar antara $-0,089$ sampai 0,527. Dengan nilai rata-rata (Mean) 0,970 dan standar deviasi sebesar 0,1158. Nilai rata-rata (Mean) mengartikan besarnya (Return On Assets) yang dihasilkan seluruh perusahaan selama periode tersebut sebesar 0,970 dan standar deviasi menggambarkan penyimpangan data sebesar 1,1158. Nilai (Return On Assets) tertinggi dicapai perusahaan PT Delta Djakarta Tbk pada tahun 2014 sedangkan nilai (Return On Assets) terendah dialami perusahaan PT Prasidha Aneka Niaga Tbk pada tahun 2018.

4) Nilai Perusahaan

Hasil pengujian statistik deskriptif pada tabel 4, dapat diketahui bahwa nilai minimum Nilai Perusahaan (PBV) sebesar 0,54 dan nilai maksimum sebesar 45,47. Hal ini menunjukkan bahwa besarnya (PBV) pada sampel penelitian ini berkisar antara 0,54 sampai 45,47. Dengan nilai rata-rata (Mean) 5,184 dan standar deviasi sebesar 7,991. Nilai rata-rata (Mean) mengartikan besarnya (PBV) yang dihasilkan seluruh perusahaan selama periode tersebut sebesar 5,184 dan standar deviasi menggambarkan penyimpangan data sebesar 7,991. Nilai (PBV) tertinggi dicapai perusahaan PT Multi Bintang Indonesia Tbk pada tahun 2014 sedangkan nilai (PBV) terendah dialami perusahaan PT Prasidha Aneka Niaga Tbk pada tahun 2015. 


\subsubsection{Pengujian Hipotesis}

Tabel 3 berikut menunjukkan pengaruh langsung modal intelektual, ukuran, dan kinerja perusahaan terhadap nilai perusahaan, serta menunjukkan pengaruh langsung modal intelektual dan ukuran terhadap kinerja perusahaan. Sementara itu, Tabel 4 menunjukkan pengaruh tidak langsung modal intelektual dan ukuran terhadap nilai perusahaan melalui kinerja perusahaan.

Tabel 3

Pengaruh Langsung Antar Variabel

\begin{tabular}{|l|c|c|c|}
\hline \multicolumn{1}{|c|}{ Pengaruh } & Koefisien Jalur & p-value & Keterangan \\
\hline Modal Intelektual $\rightarrow$ Nilai Perusahaan & 0,252 & 0,006 & Signifikan \\
\hline Modal Intelektual $\rightarrow$ Kinerja Perusahaan & 0,618 & 0,000 & Signifikan \\
\hline Ukuran Perusahaan $\rightarrow$ Nilai Perusahaan & 0,208 & 0,006 & Signifikan \\
\hline Ukuran Perusahaan $\rightarrow$ Kinerja Perusahaan & 0,323 & 0,001 & Signifikan \\
\hline Kinerja Perusahaan $\rightarrow$ Nilai Perusahaan & 0,612 & 0,000 & Signifikan \\
\hline
\end{tabular}

Note : Data diolah peneliti, 2019

Tabel 4

Pengaruh Tidak Langsung

\begin{tabular}{|l|c|c|c|c|}
\hline & $\begin{array}{c}\text { Pengaruh } \\
\text { Langsung }\end{array}$ & $\begin{array}{c}\text { Pengaruh Tidak } \\
\text { Langsung }\end{array}$ & $\begin{array}{c}\text { Pengaruh } \\
\text { Total }\end{array}$ & Keterangan \\
\hline Modal Intelektual & 0,252 & 0,378 & 0,6302 & $\begin{array}{c}\text { Kinerja perusahaan } \\
\text { sebagai variabel mediasi }\end{array}$ \\
\hline Ukuran Perusahaan & 0,208 & 0,197 & 0,4056 & $\begin{array}{c}\text { Kinerja perusahaan } \\
\text { sebagai variabel mediasi }\end{array}$ \\
\hline
\end{tabular}

Note : Data diolah peneliti, 2019

\section{H1: Modal Intelektual berpengaruh positif terhadap Nilai Perusahaan}

Berdasarkan Tabel 3 hasil uji hipotesis tingkat signifikansi modal intelektual secara langsung terhadap nilai perusahaan $0,006<0,05$. Sedangkan nilai koefisien jalur menunjukkan angka sebesar 0,252. Hasil menunjukkan bahwa modal intelektual berpengaruh positif terhadap nilai perusahaan. Dengan demikian Hipotesis 1 dapat diterima.

\section{H2: Ukuran Perusahaan berpengaruh positif terhadap Nilai Perusahaan}

Berdasarkan hasil uji hipotesis pada Tabel 3 tingkat signifikansi ukuran perusahaan secara langsung terhadap nilai perusahaan 0,006 $<0,05$. Sedangkan nilai koefisien beta menunjukkan angka sebesar 0,208. Hasil ini menunjukkan bahwa ukuran perusahaan berpengaruh positif terhadap nilai perusahaan. Dengan demikian Hipotesis 2 dapat diterima.
H3: Modal Intelektual berpengaruh positif terhadap Kinerja Perusahaan

Berdasarkan hasil uji hipotesis pada Tabel 3 tingkat signifikansi modal intelektual secara langsung terhadap kinerja perusahaan $0,000<$ 0,05 . Sedangkan nilai koefisien beta menunjukkan angka sebesar 0,618. Hasil ini menunjukkan bahwa modal intelektual berpengaruh positif terhadap kinerja perusahaan. Dengan demikian Hipotesis 3 dapat diterima.

\section{H4: Ukuran Perusahaan berpengaruh positif terhadap Kinerja Perusahaan}

Berdasarkan hasil uji hipotesis pada Tabel 3 tingkat signifikansi ukuran perusahaan secara langsung terhadap kinerja perusahaan $0,001<$ 0,05 . Sedangkan nilai koefisien beta menunjukkan angka sebesar 0,323. Hasil ini menunjukkan ukuran perusahaan berpengaruh positif terhadap nilai perusahaan. Dengan demikian Hipotesis 4 dapat diterima. 


\section{H5: Kinerja Perusahaan berpengaruh positif terhadap Nilai Perusahaan}

Berdasarkan hasil uji hipotesis pada Tabel 3 tingkat signifikansi kinerja perusahaan secara langsung terhadap nilai perusahaan $0,000<0,05$. Sedangkan nilai koefisien beta menunjukkan angka sebesar 0,612. Hasil ini menunjukkan baahwa kinerja perusahaan berpengaruh positif terhadap nilai perusahaan. Dengan demikian Hipotesis 5 dapat diterima.

\section{H6: Modal intelektual berpengaruh secara} tidak langsung terhadap nilai perusahaan melalui kinerja perusahaan.

Tabel 4 memperlihatkan hasil pengaruh modal intelektual terhadap nilai perusahaan melalui kinerja perusahaan. Tabel tersebut menunjukkan pengaruh total modal intelektual terhadap nilai perusahaan adalah sebesar 0,6302, nilai ini lebih besar dibandingkan pengaruh langsungnya yaitu sebesar 0,378. Temuan tersebut mengindikasikan kinerja perusahaan memediasi pengaruh modal intelektual terhadap nilai perusahaan. Dapat disimpulkan Hipotesis 6 diterima.

\section{H7: Ukuran Perusahaan berpengaruh secara}

tidak langsung terhadap nilai perusahaan melalui kinerja perusahaan.

Dari Tabel 4 dapat diketahui apakah kinerja perusahaan memediasi pengaruh ukuran terhadap nilai perusahaan. Tabel tersebut menunjukkan pengaruh total ukuran terhadap nilai perusahaan adalah sebesar 0,4056, nilai ini lebih besar dibandingkan pengaruh langsungnya yaitu sebesar 0,208. Dari hasil tersebut dapat disimpulkan bahwa kinerja perusahaan memediasi pengaruh ukuran terhadap nilai perusahaan, dengan demikian Hipotesis 7 diterima.

\subsection{Pembahasan Hasil Penelitian}

\subsubsection{Pengaruh Modal Intelektual Terhadap Nilai Perusahaan}

Modal intelektual telah teruji dalam penelitian ini berpengaruh positif terhadap nilai perusahaan. Hasil tersebut sejalan dengan
Resource Based Theory. Beberapa strategi memerlukan kombinasi tertentu dari sumber daya modal fisik, keuangan, manusia dan organisasi, sehingga organisasi perlu mengakses bakat manajerial tertentu untuk mendapatkan keunggulan kompetitif (Hambrick, 1987). Semakin efisiennya pengelolaan modal intelektual yang ditandai dengan produktivitas yang semakin meningkat maka nilai perusahaan akan meningkat sehingga akan menghasilkan return (laba) yang lebih bagi perusahaan. Menurut Edvinsson \& Malone (1997) salah satu keunggulan modal intelektual adalah sebagai alat untuk menentukan nilai perusahaan. Modal intelektual diyakini dapat meningkatkan nilai perusahaan.

Hasil penelitian ini sejalan dengan penelitian Abidin (2000); dan Chen et al. (2005) yang menyebutkan bahwa modal intelektual merupakan faktor utama yang dapat meningkatkan nilai perusahaan. Hal ini merupakan kabar baik yang diberikan perusahaan kepada investor berupa bukti bahwa modal intelektual yang baik akan meningkatkan nilai perusahaan.

Hasil penelitian ini memberikan penjelasan praktis bahwa dalam kurun waktu 2014-2018 investor merespons baik modal intelektual perusahaan perusahaan sampel. Sehingga dalam kurun waktu 2014-2018 modal intelektual telah sukses meyakinkan pihak investor untuk memilih perusahaan sampel sebagai pilihan untuk berinvestasi.

\subsubsection{Pengaruh Ukuran Perusahaan Terhadap Nilai Perusahaan}

Ukuran Perusahaan telah teruji dalam penelitian ini berpengaruh positif terhadap nilai perusahaan. Penentuan ukuran didasarkan pada penelitian sebelumnya oleh Novari dan Lestari (2016) yang menyebutkan semakin besar perusahaan, maka semakin dikenal perusahaan oleh masyarakat artinya semakin mudah untuk mendapatkan akses informasi terkait operasional perusahaan yang akan meningkatkan nilai perusahaan. Ukuran perusahaan juga dianggap sebagai faktor yang mampu memengaruhi nilai 
perusahaan. Menurut Dewi dan Wirajaya (2013) Ukuran perusahaan adalah peningkatan dari kenyataan bahwa perusahaan besar akan memiliki kapitalisasi pasar yang besar, nilai buku yang besar, dan laba yang tinggi. Pada penelitian ini ukuran perusahaan yang dijadikan sampel telah berhasil memberikan akses informasi operasional perusahaan dan berhasil meningkatkan nilai perusahaan.

Perusahaan besar dapat membiayai investasinya dengan mudah lewat pasar modal karena kecilnya informasi yang terjadi (Hartoyo, 2014). Berdasarkan teori tersebut maka ukuran perusahaan yang besar dianggap mampu mempengaruhi nilai perusahaan karena perusahaan yang besar dianggap mandiri dan mampu mengolah informasi yang dapat menciptakan nilai perusahaan. Hasil ini memberikan penjelasan bahwa dalam kurun waktu 2014-2018 ukuran perusahaan secara positif mempengaruhi nilai perusahaan, dengan kata lain ada peningkatan akses informasi yang dilakukan oleh investor karena kemudahan dan kejelasan akses informasi yang disediakan oleh perusahaan. Hasil penelitian ini juga berimplikasi manajerial bahwa ukuran perusahaan yang baik merupakan strategi yang baik untuk diadopsi oleh perusahaan sampel.

\subsubsection{Pengaruh Modal Intelektual Terhadap Kinerja Perusahaan}

Modal intelektual telah teruji dalam penelitian ini berpengaruh positif terhadap kinerja perusahaan. Penelitian ini menunjukkan bahwa perusahaan sampel memiliki kinerja keuangan yang baik dan dapat menarik para investor untuk berinvestasi hal ini sejalan dengan penelitian Sunarsih dan Mendra (2012) yang menunjukkan bahwa modal intelektual berpengaruh positif terhadap kinerja keuangan perusahaan.

Mavridis (2004) melakukan penelitian pada perusahaan perbankan di Jepang dimana hasilnya membuktikan bahwa kinerja yang paling baik adalah bank yang mengelola ICnya dengan lebih baik dan lebih sedikit penggunaan modal fisiknya. Hasil ini memberikan konstribusi berupa informasi tentang seberapa besar pengaruh yang dihasilkan modal intelektual terhadap kinerja perusahaan. Pada kurun waktu 2014-2018 perusahaan sampel menunjukkan kinerja keuangan yang baik, hal ini dipengaruhi oleh aset tidak berwujud perusahaan yaitu modal intelektual. modal intelektual merupakan sumber daya yang terukur untuk peningkatan competitive advantages, maka modal intelektual akan memberikan kontribusi terhadap kinerja perusahaan (Abdolmohammadi: 2005).

Lebih lanjut hasil ini berimplikasi manajerial bahwa dengan modal intelektual yang dimiliki oleh perusahaan saat ini maka perusahaan memiliki potensi untuk semakin meningkatkan kinerja perusahaan. Dengan semakin baiknya kinerja perusahaan maka semakin besar pula kesempatan perusahaan dalam menghasilkan laba dan semakin memperkuat kondisi internal perusahaan itu sendiri.

\subsubsection{Pengaruh Ukuran Perusahaan Terhadap Kinerja Perusahaan}

Ukuran perusahaan menunjukkan pengaruh positif terhadap kinerja perusahaan. Hasil ini sejalan dengan beberapa penelitian seperti Rompas (2013) yang menunjukkan bahwa ukuran perusahaan memiliki efek positif dan signifikan terhadap kinerja perusahaan dan penelitian Darmawati (2004) yang menyatakan perusahaan besar pada dasarnya memiliki kekuatan finansial yang lebih besar dalam menunjang kinerja.

Dari hasil yang ditunjukkan maka ukuran perusahaan memiliki dampak terhadap manajerial untuk periode 2014-2018. Pertama ukuran perusahaan diperlukan oleh perusahaan untuk menunjang kinerja perusahaan karena ukuran perusaan memberikan akses informasi mengenai aset yang dimiliki selama periode tertentu sehingga dapat memberikan motivasi kepada pihak manajerial untuk meningkatkan kinerja perusahaan guna mengembangkan aset yang dimiliki oleh perusahaan. 


\subsubsection{Pengaruh Kinerja Perusahaan Terhadap Nilai Perusahaan}

Hasil penelitian ini menunjukkan kinerja perusahaan berpengaruh positif terhadap nilai perusahaan. Kinerja perusahaan yang baik memungkinkan terciptanya nilai perusahaan sehingga hubungan kinerja perusahaan dan nilai perusahaan berbanding lurus. penelitian terdahulu yang mendukung dugaan bahwa kinerja perusahaan (profitability) berpengaruh positif terhadap nilai perusahaan antara lain Allazy (2013).

Kinerja Perusahaan berpengaruh positif pada nilai suatu perusahaan karena prospek perusahaan yang baik akan diperoleh dari profit yang tinggi oleh sebab itu akan banyak investor yang berpartisipasi didalamnya sehingga permintaan saham akan semankin meningkat (Mardiyati et al., 2012). Semakin baik kinerja perusahaan maka akan menunjukan prospek perusahaan yang berkualitas baik sehingga pasar akan merespon positif sinyal tersebut dan nilai perusahaan akan meningkat pula (Sujono dan Soebiantoro, 2007). Berdasarkan signalling theory, kinerja perusahaan yang baik akan mengundang ketertarikan investor terhadap perusahaan. Semakin banyak investor yang tertarik dengan perusahaan berarti perusahaan telah berhasil menciptakan nilai kepada pasar. Sehingga peran kinerja perusahaan merupakan faktor penting yang diperlukan untuk menciptakan nilai perusahaan.

Pada periode penelitian (2014-2018) perusahaan berhasil menunjukkan pengaruh positif kinerja perusahaan terhadap nilai perusahaan. Berdasarkan hal ini maka secara manajerial perusahaan dapat memberikan konstribusi dan meminimalisasi kesalahan dalam kaitannya menciptakan nilai perusahaan.

\subsubsection{Pengaruh Modal Intelektual terhadap nilai perusahaan melalui kinerja perusahaan.}

Peran penting modal intelektual dalam peningkatan kinerja keuangan telah dibuktikan dalam penelitian ini. Menurut Abdolmohammadi, (2005) modal intelektual merupakan sumber daya yang akan memberikan kontribusi terhadap kinerja perusahaan. Appuhami (2007) menyatakan bahwa semakin besar nilai modal intelektual maka semakin efisien penggunaan modal perusahaan, sehingga menciptakan value added bagi perusahaan. Physical capital sebagai bagian dari modal intelektual menjadi sumber daya yang menentukan kinerja perusahaan. Dalam penelitian ini modal intelektual diyakini dapat meningkatkan kinerja perusahaan. Peningkatan kinerja perusahaan disebabkan oleh efisiensi pengelolaan modal oleh perusahaan.

Jumingan (2005) menjelaskan bahwa kinerja keuangan merupakan gambaran kondisi keuangan perusahaan pada suatu periode tertentu baik menyangkut aspek penghimpunan dana maupun penyaluran dana yang biasanya diukur dengan indikator kecukupan modal, likuiditas dan profitabilitas. Muliani, (2014) menerangkan bahwa kinerja keuangan berpengaruh positif terhadap nilai perusahaan. Hal ini berarti kinerja keuangan perusahaan dapat meningkatkan nilai perusahaan. Dalam penelitian ini kinerja perusahaan berpengaruh positif terhadap nilai perusahaan yang berarti prospek perusahaan baik karena tercipta nilai perusahaan.

\subsubsection{Pengaruh Ukuran perusahaan terhadap nilai perusahaan melalui kinerja perusahaan.}

Kinerja perusahaan dapat dilihat berdasarkan ukuran perusahaan. Ukuran perusahaan menentukan penggunaan dana eksternal yang akan digunakan oleh perusahaan. Semakin banyak aktiva yang dimiliki dan semakin lancar tingkat perputaran aktiva maka akan semakin besar laba yang diperoleh perusahaan (Kartikaningsih, 2013). Menurut Kartikaningsih (2013) ukuran perusahaan memiliki pengaruh terhadap kinerja perusahaan. Perusahaan sampel pada penelitian ini menunjukkan kinerja keuangan yang baik. Hal ini dipengaruhi oleh ukuran perusahaan. Penentuan skala besar kecilnya perusahaan dapat ditentukan berdasarkan total penjualan, total asset, rata-rata tingkat penjualan (Seftianne, 2011). Investor meyakini bahwa ukuran yang besar dapat mempengaruhi kinerja perusahaan menjadi lebih baik dan meningkatkan laba perusahaan. 
Kinerja keuangan merupakan prestasi kerja yang telah dicapai oleh perusahaan dalam suatu periode tertentu dan tertuang pada laporan keuangan perusahaan yang bersangkutan (Munawir, 1998). Ketika kinerja perusahaan dapat menghasilkan laba secara baik maka akan menarik minat investor. Sehingga kinerja perusahaan berpengaruh positif terhadap nilai perusahaan dan dapat menciptakan nilai terhadap investor untuk berinvestasi pada perusahaan.

\section{Kesimpulan dan Saran}

\subsection{Kesimpulan}

Modal intelektual perusahaan food and beverage pada penelitian ini cukup baik dan efisien dalam memberikan pengaruh positif terhadap nilai perusahaan. Hal ini menunjukkan terciptanya nilai perusahaan yang ditunjang dengan modal intelektual yang baik dan efisien akan membantu perusahaan dalam menjalankan aktivitas bisnisnya.

Ukuran perusahaan dari perusahaan food and beverage pada penelitian ini menunjukkan pengaruh positif terhadap nilai perusahaan. Ini menunjukkan bahwa secara material perusahaan mampu menjamin pengembalian aset untuk menciptakan nilai perusahaan yang baik. Perusahaan telah dipercaya oleh investor dalam menjamin return dan dianggap memiliki prospek yang baik di masa yang akan datang. Konsekuensi nya adalah investor semakin berminat untuk melakukan investasi dan hal ini menyebabkan nilai perusahaan akan meningkat.

Modal intelektual perusahaan food and beverage pada penelitian ini cukup baik dan efisien dalam memberikan pengaruh positif terhadap kinerja perusahaan. Hal ini menunjukkan peran modal intelektual dalam menunjang kinerja perusahaan baik. Kinerja perusahaan ditunjang oleh mutu SDM, karyawan, dan modal struktural sehingga mampu menghasilkan kinerja perusahaan yang baik.

Ukuran perusahaan dari perusahaan food and beverage pada penelitian ini menunjukkan pengaruh positif terhadap nilai perusahaan. Ini menunjukkan bahwa total aset yang dimiliki oleh perusahaan berdampak terhadap kinerja keuangan perusahaan. Semakin baik ukuran perusahaan akan memberikan motivasi dan dampak positif terhadap kinerja perusahaan.

Kinerja perusahaan dari perusahaan food and beverage pada penelitian ini menunjukkan pengaruh positif terhadap nilai perusahaan. Hal ini berarti nilai perusahaan meningkat karena return yang dihasilkan kinerja perusahaan berjalan dengan baik dan perusahaan. Kinerja perusahaan memberikan sinyal positif kepada para investor untuk melakukan investasi pada perusahaan,yang selanjutnya berdampak positif terhadap nilai perusahaan.

Modal intelektual berpengaruh positif terhadap nilai perusahaan melalui kinerja perusahaan. Hal ini berarti laba yang dihasilkan perusahaan ditambah dengan pengelolaan modal intelektual secara efektif akan menciptakan nilai perusahaan.

Ukuran perusahaan berpengaruh positif terhadap nilai perusahaan melalui kinerja perusahaan. Hal ini berarti laba yang dihasilkan perusahaan ditambah dengan akses informasi yang baik akan menciptakan nilai perusahaan.

\subsection{Saran}

Disarankan kepada peneliti selanjutnya menggunakan objek penelitian yang lebih luas karena pada penelitian ini objek perusahaan manufaktur food and beverage (BEI) kurang mampu menjelaskan seluruh objek perusahaan manufaktur di BEI. Diharapkan untuk perusahaan yang menjadi sampel ini dapat meningkatkan nilai perusahaan melalui kinerja perusahaan dan didorong oleh modal intelektual dan ukuran perusahaan. Investor sebaiknya memperhatikan modal intelektual dan ukuran perusahaan sebagai dasar dalam mengambil keputusan untuk berinvestasi.

\section{Ucapan Terimakasih}

Puji syukur kehadirat Allah SWT saya panjatkan karena dapat menyelesaikan proposal tesis ini. Saya mengucapkan terimakasih sebesarbesarnya pada Ibu Prof. Dr. Muslichah, M.Ec 
yang telah banyak memberikan bantuan, baik moral maupu material untuk penyusunan tesis ini.

Terimakasih saya sampaikan kepada jajaran pengajar, rekan belajar dan staf program pascasarjana STIE Malangkucecwara yang telah mendukung dalam penulisan tesis ini. Terimakasih juga saya sampaikan kepada teman saya Aprodhita Firstawindi Avalukiteswara, S.E yang selalu memberikan bantuan moral.

Akhirnya saya mengucapkan terimakasih pada ayahku tercinta Widodo yang menjadi orang utama yang mendukung penulisan tesis ini. Semoga segala bantuan yang diberikan oleh semua pihak senantiasa mendapat balasan yang baik dari Allah SWT.

\section{Daftar Pustaka}

A. Ross, Stephen, dkk. 2015. Pengantar Kuangan Perusahaan. Jakarta: Salemba Empat.

Abidin, Sawarjuwono dan Kadir, 2003, "Intellectual Capital Disclosure Commitment : Myth or Reality?", Journal of Intellectual Capital, Vol.13, No. 1, pp. 3956

Ahmed Bounfour, (2003),"The IC-dVAL approach", Journal of Intellectual Capital, Vol. 4 Iss: 3 pp. 396 - 413

Akpinar, E. 2014. The Use of Interactive Computer Animations Based on POE as a Presentation Tool in Primary Science Teaching. Diakses secara online. Vol 23, no. 4, pp: $527-537$.

Allazy, Muhammad Reza. 2013. Pengaruh Leverage, Profitabilitas, Likuiditas, Kebijakan Deviden, Ukuran Perusahaan dan Pertumbuhan Perusahaan Terhadap Nilai Perusahaan. Jurnal Ilmiah Universitas Bakrie. Vol.1, No.02.

Ang, Robert. 1997. Buku Pintar Pasar Modal Indonesia (The Intelligent Guide to Indonesian Capital Market). Jakarta: Mediasoft Indonesia.

Berzkalne, I., \& Zelgalve, E. (2014). Intellectual capital and company value. Procedia-Social and Behavioral Sciences, 110, 887-896.
Bchini, B. (2015). Intellectual capital and value creation in the Tunisian manufacturing companies. Procedia economics and finance, 23, 783-791.

Bontis, N., William, C. C. L., \& Richardson, R. (2000). Intellectual capital and business performance in Malaysian industries. Journal of Intellectual Capital, 1(1), 85- 100.

Chen, et al. 2005. An empirical investigation of the relationship between intellectual capital and firm's market value and financial performance. Journal of Intellectual Capital, Vol 6, Issue 2.

Cheng, C., Li, S., Zhao, W., Wei, Q., Nie, S., Sun, S., and Zhao, C, 2012, The Hydrodynamic Permeability and Surface Property of Polyethersulfone Ultrafiltration Membranes with Mussel-Inspired Polydopamine Coatings, Journal of Membrane Science, s 417 - 418 : 228 - 236.

Ernawati dan Widyawati, 2015. Pengaruh Profitabilitas, Leverage dan Ukuran Perusahaan Terhadap Nilai Perusahaan. Jurnal Ilmu \& Riset Akuntansi Vol. 4 No. 4 (2015)

Fajarini, Indah \& Riza Firmansyah. 2012. "Pengaruh Intellectual Capital Terhadap Kinerja Keuangan Perusahaan (Studi Empiris Perusahaan LQ 45)". Jurnal Dinamika Akuntansi. Vol.4. No.1.

Ferraro, O., \& Veltri, S. (2011). The Value Relevance of Intellectual Capital on the Firm's Market Value: An Empirical Survey on the Italian Listed Firms. International Journal of Knowledge-Based Development, 2, 66-84.

Firer, S dan Williams, M. 2003. Intellectual Capital and Traditional Measures of Corporate Performance. Journal of Intellectual Capital. Vol. 4 No. 3, pp. 348360.

Heidarpoor, Farzaneh, and Malekpoor, Somayeh. 2012. Survey The Effective Factors on Tobin's Index In Tehran Stock Exchange, World Applied Sciences Journal, 18 (4): 575-579. 
Hong, C.,H., Lee, Y.,B.,Bae, J.,Y., Nam., B., U., Hwang, T., W., Performance of Polypropylene/Clay Nanocomposit for Automotive Parts Applications, J. Ind. Eng. Chem., 2005, 76-82.

Idah Zuhroh,(2019),"The Effects of Liquidity, FirmSize, and Profitability on the Firm Value with Mediating Leverage" in The 2nd International Conference on Islamic Economics, Business, and Philanthropy (ICIEBP)

Jogiyanto. (2000). Teori Portofolio dan Analisis Investasi. Edisi Kedua, BPFE UGM,Yogyakarta.

Khumairoh et al (2015). Pengaruh Leverage, Profitabilitas, dan Ukuran Perusahaan Terhadap Nilai Perusahaan. ISSN 24600784

Khlif, Hichem, Achraf Guidara, Mohsen Souissi, 2015. Corporate Social and Environmental Disclosure and Corporate Performance Evidence From South Africa and Morocco, Journal of Accounting in Emerging Economies, 5 (1): 51-69.

Li, Y., \& Zhao, Z. (2018). The dynamic impact of intellectual capital on firm value: evidence from China. Applied Economics Letters, 25(1), 19-23.

Mehralian, G., Rasekh, H. R., Akhavan, P., \& Sadeh, M. R. (2012). The Impact of Intellectual Capital Efficiency on Market Value: An Empirical Study from Iranian Pharmaceutical Companies. Iranian Journal of Pharmaceutical Research, 11, 195-207.

Mhedhbi, I. (2013). Identifying The Relationship Between Intellectual Capital And Value Creation Of The Company Using Structural Equations Analysis-The Case Of Tunisia. Journal of Business Studies Quarterly, 5(2), 216.

Morris, R. D. (1987). Signaling, Agency Theory and Accounting Policy Choice, Accounting and Business Research, Vol. 18, No. 69, pp 47- 56
Nabavand, Behrooz, and Rezaei, Javad and. 2015. Review Between Tobin's Q With Performance Evaluation Scale Based Accounting and Marketing Information In Accepted Companies In Tehran Stock Exchange, Journal of Applied Environmental and Biological Sciences, 4(5S);138-146.

Nawaiseh, Musa Abdel Latif Ibrahim al. 2017. The Impact of the Financial Performance on Firm Value: Evidence from Developing Countries, International Journal of Applied Business and Economic Research, 15(16): 241-253

Petty, R. and Guthrie, J. 2000. Intellectual Capital Literature Review:Measurement, Reporting and Management. Journal of Intellectual Capital, 1 (2): 155- 176.

Rompas, Gisela Prisilia.2013. Likuiditas Solvabilitas dan Rentabilitas terhadap Nilai Perusahaan BUMN yang terdaftar BEI. Jurnal EMBA 253Vol.1 No.3 September 2013

Sawarjuwono, Tciptohadi, Agustine Prihatin K. 2003. "Intellectual Capital : Perlakuan, Pengukuran dan Pelaporan". Jurnal Akuntansi dan Keuangan Vol. 5, No. 1.

Seftianne dan Handayani. 2011. Faktor - Faktor yang Mempengaruhi Struktur Modal pada Perusahaan Publik Sektor Manufaktur. Jurnal Bisnis dan Akuntansi, Volume 13, No. 1, April 2011, Halaman 39 - 56.

Setiadharma, S., \& Machali, M. (2017). The effect of asset structure and firm size on firm value with capital structure as intervening variable. Journal of Business \& Financial Affairs, 6(4), 1-5.

Shiri, M. M., Mousavi, K., Pourreza, A., \& Ahmadi, S. (2012). The effect of intellectual capital on market value added. Journal of Basic and Applied Scientific Research, 2(7), 7214-7226.

Spence, Michael. (1973) "Job Market Signaling”. The Quarterly Journal of Economics, 87, (3) (Aug., 1973), pp. 355-374. The MIT Press.) 
Sudibya dan Restuti. Juni 2014. Pengaruh Modal Intelektual Terhadap Nilai Perusahaan Dengan Kinerja Keuangan Sebagai Variabel Intervening. Volume 18 - Nomor 1, hal 1429.

Sujoko dan Ugy Soebiantoro. 2007. Pengaruh Struktur Kepemilikan Saham, Leverage, Faktor Interen dan Faktor Eksteren terhadap Nilai Perusahan. Jurnal Manajemen dan Kewirausahaan. Vol 9, No. 1.

Tanideh, S. (2013). Relationship between innovation capital and intellectual capital with value and financial performance. Life Science Journal, 10, 251-254.

Tisna, G., \& Agustami, S. 2016. Pengaruh Good Corporate Governance Dan Ukuran Perusahaan Terhadap Kinerja Keuangan Perusahaan (Pada Perusahaan Perbankan Yang Terdaftar Di Bursa Efek Indonesia (Bei) Tahun 2010-2014). Jurnal Riset Akuntansi Dan Keuangan, 4(2), 1035-1046.
Ulum, Ihyaul. 2008. "Intellectual Capital Performance Sektor Perbankan di Indonesia". Jurnal Akuntansi dan Keuangan, Vol. 10, No. 2. Universitas Muhammadiyah Malang.

Veronica, Sylvia, dan Siddharta Utama. 2005. Pengaruh Struktur Kepemilikan, Ukuran Perusahaan, dan Praktek Corporate Governance terhadap Pengelolaan Laba (Earnings Management). Artikel yang Dipresentasikan pada Simposium Nasional Akuntansi 8 Solo.

Yusuf dan P. Sawitri. (2009). "Modal Intelektual dan Market Performance PerusahaanPerusahaan yang Terdaftar di Bursa Efek Indonesia". Proceeding PESAT (Psikologi, Ekonomi, Sastra, Arsitektur \& Sipil) Universitas Gunadarma, Depok, 49-55.

Zuhroh, I. (2019). The Effects of Liquidity, Firm Size, and Profitability on the Firm Value with Mediating Leverage. KnE Social Sciences, 203-230. 